\title{
Article \\ Content Validation of a Semi-Structured Interview to Analyze the Management of Suffering
}

\author{
Carmen Sánchez-Guardiola Paredes *, Eva María Aguaded Ramírez and Clemente Rodríguez-Sabiote \\ Department of Methodology in Research and Diagnostic in Education, Universidad de Granada, \\ 18071 Granada, Spain; eaguaded@ugr.es (E.M.A.R.); clerosa@ugr.es (C.R.-S.) \\ * Correspondence: carmengra@correo.ugr.es
}

Citation: Sánchez-Guardiola

Paredes, C.; Aguaded Ramírez, E.M.;

Rodríguez-Sabiote, C. Content

Validation of a Semi-Structured Interview to Analyze the Management of Suffering. Int. J. Environ. Res. Public Health 2021, 18, 11393. https:// doi.org/10.3390/ijerph182111393

Academic Editor: Paul B. Tchounwou

Received: 10 September 2021

Accepted: 25 October 2021

Published: 29 October 202

Publisher's Note: MDPI stays neutral with regard to jurisdictional claims in published maps and institutional affiliations.

\begin{abstract}
This work involves the content validation of a semi-structured interview, whose objective is to learn about the management of suffering in people. The interview items have been classified into several categories that define the suffering construct. For the content validation of the instrument, in addition to initially conducting a scientific review on the subject, the procedure known as expert judgement has been used. The results obtained in terms of the content validity achieved in the dimensions and areas assessed are, in general, satisfactory. However, some of these dimensions and certain areas have not exceeded the required minimum values for content validity. Therefore, it is necessary to modify the items comprising these dimensions in the areas evaluated with the additional incorporation of the qualitative suggestions for improvement indicated by the experts. As for agreement among experts, the results point to moderate agreement, which, moreover, is not due to chance.
\end{abstract}

Keywords: expert judgement; content validity; suffering; concordance

\section{Introduction}

The aim of many areas of knowledge, in particular, Philosophy, Psychology, Psychiatry, Medicine, Nursing, Sociology, Educational Sciences, Linguistics, and other related fields, has been for years to search for the most effective way to alleviate and manage human suffering in any of its facets. To this end, these various fields of knowledge have been explored in the scientific literature.

Human suffering and its management is a progressive topic of interest that affects human beings throughout their lives. Reference [1] states that suffering is individual, unique, and inherent to each person. It is characterized by its complexity and multidimensionality, where psychological, spiritual, socio-cultural, and familial needs, etc. must be addressed. A thorough understanding of the nature of suffering and its associated factors is required in order to alleviate unnecessary suffering.

All of this is interdisciplinary work as the human being is multidimensional. Reference [2] argues that it is not the body that suffers but the person, and the person is a unit, not a mind on one side and a body on the other. Moreover, Reference [3] agrees along the same lines:

We are complex units where the objective and the subjective, the environment and the biography are integrated, but we are units, therefore, those who suffer are us as a whole, not just the mind or the mind on the one hand and the body on the other. No. It is the whole, the unity (p. 74).

There are no fixed sources of human suffering. The impact of events is dependent on subjectivity. This idea has been defended by authors such as in [4-7], among others, who define suffering as a person's attitude towards problems. Suffering is not only a lived reality, but also a certain way of interpreting that experienced reality. The interpretation of experience is not only an attempt to give sense or meaning to the phenomenon, but is one of its inherent elements. Each conceptualization makes sense on the basis of a series 
of premises implicit to that concept. In other words, on the basis of a set of previous interpretations that determine it. Behind each of the conceptualizations there is a narrative (about the world, human beings, good and evil, and other matters) that drives the concept of suffering. Therefore, every conceptualization of suffering presupposes an interpretation derived from a previous, implicit, and determinant, although invisible, narrative.

Reference [8] argues that the treatment for suffering should be delivered by holistic programs that treat the whole person, given that people are multidimensional beings. For instance, the authors such as in [1,9-11] and others agree with this concept. In research such as in [11], it is argued that there is empirical evidence that an alternative pedagogical treatment of suffering by practitioners would be for people to be cared for via holistic programs, with treatments that take into account the various dimensions of the human being: The affective, cognitive, and emotional, in order to improve their quality of life. Alleviating suffering caused by illnesses through biomedical sciences is no longer sufficient. Moreover, the new framework encompasses both the personal and institutional dimensions. This perspective would be very enriching and helpful in the alleviation of suffering. Empirical data and evidence from this research show that with treatments that care for the human being holistically, levels of anxiety, depression and, ultimately, suffering are reduced in the majority of cases.

Opportunities exist for education professionals, social educators, and pedagogues to improve situations of suffering in society. The study of the topic of suffering can provide invaluable information for all of the researchers to be able to understand the nature of suffering in each life story. Studies on suffering by [7,12-18], among others, show that it is still a work in progress from a pedagogical point of view, but not from the psychological, medical or palliative care perspectives, etc. where studies are more advanced.

The authors such as in [19] stress the importance of educating people on how to manage suffering, as it leads to a high culture with the right conditions for the human to grow and mature. Notions in favor of compassion, fear, eliminating suffering, etc. are characterized as an effective and real denial of life. This type of education would produce beneficial effects. The educational perspective on the management of suffering presupposes preparing the human being according to the actual needs of everyday life. Reference [20] explains that pain has its usefulness in preventing or helping to expel present or potentially bad aspects of life, sometimes serving to protect the injured organ. A similar response can be given with regards to psychological and moral suffering. One of its essential functions is to teach, not in an abstract informative way but by its very vital negativity, just as pleasure, if properly embraced, has a positive function in life.

Reference [18] attempts to answer the question: What is the purpose of negative affective experience? Attempts have been made to advance the virtue-theoretic perspective on the value of suffering. The general view is that suffering is necessary for the cultivation and expression of important forms of virtue, without which a happy and flourishing life is impossible. Certain forms of suffering in appropriate circumstances are: (1) Virtuous motives. (2) The promotion of the development of virtues associated with strength of character, vulnerability, morality, and wisdom. (3) The communication of virtue to others, fostering the social virtues associated with justice, love, and trust.

Moreover, suffering is a very broad and very complex phenomenon, a concept which is difficult to delimit and understand in just one term. An attempt has been made to narrow down the concept of suffering by investigating four different issues in the groups of people interviewed.

1. Suffering due to a partner relationship;

2. Suffering due to illness;

3. Suffering due to a failure to adapt to the environment;

4. Suffering due to financial problems.

As already classified by some authors, such as the great philosopher in [21], other factors that can give rise to suffering and frustration in the person are specified. These include 
sexuality and eroticism, fear of death, poor health, economic instability, unrecognized achievements, religion, and politics.

This type of emotional pain or suffering includes pain caused by the break-up of a partner relationship, pain due to the serious or chronic illness or the death of a loved one, pain due to a failure to adapt to the environment caused, for example, by estrangement from loved ones such as children, partners, and parents, etc., pain due to a major disappointment in any area, for example, financial and economic matters, etc. [10].

Therefore, the intention is to establish communication links between reality, theory, and practice in order to draw conclusions that improve the management of the suffering of these people, their families, and friends without ignoring improvements in emotional, educational, medical, and clinical management and care. In general, this is a multidisciplinary and holistic approach due to the multidimensional nature of human beings. In the field of social sciences, researchers typically design different types of questionnaires such as tests, surveys, interviews (structured, semi-structured, and unstructured), and scales, etc. to collect data that respond to their study variables. Sometimes standardized tests are used and other times the researcher develops a data collection instrument according to the needs and objectives of the particular study. These instruments consist of items that contain indicators formed by a theoretical framework that aims to make the constructs to be measured observable.

According to [22] (p. 17) "indicators tend to play a mediating role between the scientific literature and the empirical, i.e., between the theoretical framework and the external world". Indicators point to and refer to observable, measurable, and empirically detectable features and characteristics.

The use of indicators for the efficient measurement or observation of a theoretical construct demands that these explanatory indicators satisfy a series of requirements. They must describe the reality that is going to be studied. Therefore, they must fulfil their function with a validity and reliability index in order for the results obtained from the research to have scientific rigor.

Validity in general has been argued by [23] (p. 1) as "the accuracy with which adequate and meaningful measurements can be made with a test". In his opinion, some of the characteristics to be highlighted by measurement would be addressing increasing validity, basic values, accuracy in decision-making, homogeneity, and sequential development of the items. Similarly, the authors in [24] point out that content validity determines the degree to which an instrument reflects the specific content domain of what is to be measured. Moreover, it is responsible for assessing whether the instrument contemplates the dimensions of the construct to be measured. Therefore, the instrument is considered valid if it contemplates each and every one of the elements related to the concept of the construct $[25,26]$.

Other authors such as in [27] state that content validity aims to guarantee that the indicators selected adequately represent the construct of interest, on the basis that the construction of the items is developed from the conceptualization of the variable to be measured.

The purpose of content validity is to provide evidence that the semantic definition is included in the items constructed, that they are relevant to the construct, and that they adequately address each of the dimensions proposed in the semantic definition [28].

Reference [17] explains that validity is usually studied using several components [17]: Content validity, criterion validity, and construct validity. The three are distinct and the use of each depends on the type of test being conducted. Researchers are generally interested in determining the content validity of measurement instruments such as self-developed questionnaires, as there is not usually any specific external criterion for these instruments.

Essentially, the so-called "expert judgement" procedure is used as a way of assessing content validity, in addition to expert agreement and the precise determination of whether the instrument is valid or not, and whether it actually measures what is required. Therefore, it is very important to quantify the degree of content validity of the instrument using indicators. 
In this particular case, the validity was assessed in relation to all of the four aspects considered (content, wording, number, and relevance of the items). This procedure is useful as it improves the understanding of what is being measured in the test. If the test is valid, it is reliable, but not vice versa. From this, the content validity of the measurement instrument is determined by means of Aiken's V coefficient and the interval scale, in order for the researchers to have guidance on handling the index and using it to further support the assessment made by the experts' judgement.

Following this conceptual contribution, this work aims to validate an instrument to analyze the extent to which the items in the various categories are successful. The objective of this validation is to obtain an effective, reliable, and user-friendly instrument. The importance and need for the validation of data collection instruments have been the priority of many contemporary research studies, as References [29,30], among others, state in their work, and for whom the validation of the instrument is a crucial phase, which verifies that the data and conclusions obtained and practices carried out have or do not have sufficient substance and foundation.

\section{Methods}

\subsection{Instrument}

The instrument used in this research was the semi-structured interview specifically designed on an ad hoc basis and validated by expert judgement. Based on the categories that emerged as a result of the literature review, the objectives of this research will be answered. This interview has been called "the management of suffering in people suffering from illness, relationships, economic problems, and adaptation to the environment" (see Appendix A).

The sequence of items is divided into the following categories of analysis:

Socio-demographic data;

Suffering;

Love in the dimension of family, friends, and partner;

Acceptance;

Non-acceptance;

Resignation;

Spiritual dimension;

Verbal and non-verbal communication;

Pain;

Fear;

Transience;

Gratitude;

Compassion;

Hope;

Palliative care;

Sadness;

Resilience;

Happiness/life satisfaction, well-being.

Through each of these categories, a series of items have been elaborated in order to obtain the information addressed.

The data collection took place in different places as each informant preferred, although always in quiet places that safeguarded confidentiality. The process was recorded on audio and later transcribed.

Finally, we state that each of the interviews carried out is developed in a different way, taking into account the context and the reporting subject. The interviews have been recorded on audio with the consent of each of the interviewed subjects in order to preserve the collection of informative data.

Therefore, this research is framed within the proposed ethical considerations: Informed consent, avoiding deception of research participants, respecting participants' pri- 
vacy, upholding accuracy of data and interpretation, and respect for the individual. Moreover, we state that, with respect to the confidentiality of the participants, any identifying data that could recognize them have been removed, thus preserving anonymity in each and every one of the interviews. In addition, with respect to the consent document, each and every one of them was informed of the purpose of the research and agreed to it.

The semi-structured interviews provided an abundance of data, which were refined and analyzed to arrive at a final result. This research study was marked by data saturation.

\subsection{Participants}

It should be mentioned that the questionnaire is aimed at a sample of 22 respondents. With regards to the section on suffering due to illness, it was carried out with chronically ill patients from hospitals in Granada (Spain). On the part of the hospital, in a direct and intentional selection sample, those subjects with the highest degree of loneliness were assigned to the research. Therefore, the type of sampling was incidental. The participating sample consisted of four subjects of different genders between 41 and 80 years of age, from different cities in Spain and America.

With regards to the other sections on suffering due to economic problems, relationships, and adaptation to the environment, the participant sample was made up of informants of different genders between 40 and 65 years of age (Table 1, identification sheet) who provided data explaining the phenomenon of suffering until the information was saturated. Therefore, the sampling is non-probabilistic and intentional. As [31] points out, the final number of the sample is obtained when the informants do not present any more answers to the explanation of the phenomenon, reaching saturation of the testimonies or information.

Similarly, the so-called "snowball" technique was also used in sampling. This is a non-probability sampling technique used by researchers to identify potential subjects in studies where subjects are difficult to find. What is relevant in this research work is the importance of the word of the people interviewed and the information provided by them, as it is thanks to them that the results of this work will be obtained. These ideas have been defended by [32] who supports the study of narrative, as it is the way in which human beings experience the world. This general notion carries over to the conception that education is the construction and reconstruction of personal and social stories. In addition, that teachers and learners are narrators and characters of their own and others' stories. This concept can be applied in the interaction between patient/educator, interviewee/educator, learner/educator as mutual learning takes place through the knowledge of the informants life stories. Thanks to these life stories, it will be possible to intervene in how to teach how to manage, lessen or alleviate suffering. As [33] explained, healing is bilateral, there is mutual teaching and learning on both sides. 
Table 1. Identification sheet of interviewees.

\begin{tabular}{|c|c|c|c|c|c|c|}
\hline Identification & Sex & AGE & City of Residence & Educational Level & Profession & Religion-Beliefs \\
\hline S.1 & Female & 41 & Miami & High school & Housekeeping & Catholic believer \\
\hline S.2 & Male & 65 & Churriana de la Vega & Primary studies & Waitress & Believer \\
\hline S.3 & Male & 50 & Santa Fe & Primary studies & hostelry & Catholic believer \\
\hline S.4 & Female & 80 & Granada & Primary studies & Housekeeping & Creyente \\
\hline S.5 & Female & 48 & Granada & University education & Professor & Catholic believer \\
\hline S.6 & Female & 44 & Cúllar Vega & University education & Administrative assistant & Catholic believer \\
\hline S.7 & Female & 40 & Granada & University education & Lawyer & Catholic believer \\
\hline S.8 & Female & 64 & Miami & University education & Realtor & Catholic believer \\
\hline S.9 & Male & 41 & Granada & University education & Security guard & Catholic believer \\
\hline S.10 & Female & 58 & Granada & University education & Housewife & Catholic believer \\
\hline S.11 & Female & 62 & Granada & Primary studies & Housewife & Catholic believer \\
\hline S.12 & Female & 50 & Granada & University education & Professor & Believer \\
\hline S.13 & Female & 47 & Huétor Vega & Primary studies & Geriatric assistant & Catholic believer \\
\hline S.14 & Female & 60 & Granada & Primary studies & Housewife & Catholic believer \\
\hline S.15 & Male & 36 & Granada & High school & Businessman & Atheist \\
\hline S.16 & Female & 46 & Granada & University education & Professor & Believer \\
\hline S.17 & Female & 57 & Alhendín & University education & Technical support analyst & Catholic believer \\
\hline S.18 & Female & 54 & Granada & University education & Housewife & Catholic believer \\
\hline S.19 & Male & 53 & Granada & University education & Administrative SAE & Agnostic \\
\hline S.20 & Female & 49 & Churriana de la Vega & University education & Professor & Catholic believer \\
\hline S.21 & Female & 42 & Granada & University education & Educational counselor & Believer \\
\hline S.22 & Male & 57 & Mallorca & University education & Lawyer & Catholic believer \\
\hline
\end{tabular}

Source: Author's own elaboration.

\subsection{Content Validation}

In order to validate the semi-structured interview's content, the assessment made by various experts on different aspects of the interview was taken into account. Reference [31] proposed a series of criteria for the selection of experts, among which we highlight:

(a) Experience in performing judgements and making decisions, based on evidence on expertise, e.g., degrees, research, publications, etc.;

(b) Reputation in community;

(c) Availability and willingness to participate;

(d) Impartiality and inherent qualities such as self-confidence and adaptability.

In our case, for the selection of experts we have considered a mixed criterion. In other words, their availability and willingness to participate and experience in the topic under evaluation based on evidence on expertise, namely research and publications. In this sense, a list of 10 experts from the university teaching profession assessed the semi-structured interview. All of them are people with extensive knowledge and proven experience in the area of interest and are therefore qualified to answer the questions posed. They come from different educational backgrounds, approach the problem experimentally as opposed to theoretically, and are from different professional experiences. They are intended to help improve the quality of the analysis.

In terms of their distinctive characteristics, it should be highlighted that a total of four men and six women aged between $45-65$, with an average age of 55, participated. They belonged to different departments in the University of Granada (Pedagogy: 3; Business Organization: 2; Translation and Interpretation: 1; Political Science and Administration: 1; Voice Pedagogy: 1; CAMD: 1; Philanthropy and Business: 1). There was a range of professional categories, namely 3 tenured university professors, 1 retired tenured university professor, 1 associate professor, 1 tenured special education professor, 1 sports doctor, 1 on a permanent doctoral contract, 1 entrepreneur and philanthropist, and 1 on a postdoctoral contract. All this can be seen in Table 2. 
Table 2. Expert's identification data.

\begin{tabular}{|c|c|c|c|c|c|}
\hline $\begin{array}{l}\text { Expert } \\
\text { Code }\end{array}$ & Sex & $\begin{array}{l}\text { Years of Experience } \\
\text { at the University }\end{array}$ & Department & University & Current Professional Category \\
\hline 1 & $\mathrm{H}$ & 25 & Pedagogy & UGR & University professor (retired) \\
\hline 2 & M & 15 & Business organization & UGR & University professor \\
\hline 3 & $\mathrm{H}$ & 40 & Philanthropy and Business & \multirow{2}{*}{$\begin{array}{c}\text { Harvard } \\
\text { Business School } \\
\text { UGR }\end{array}$} & Speaker and Philanthropy \\
\hline 4 & M & 20 & \multirow{3}{*}{$\begin{array}{c}\text { Traduction and interpretation } \\
\text { Polítical science and } \\
\text { Administration } \\
\text { Pedagogy }\end{array}$} & & University professor \\
\hline 5 & $\mathrm{H}$ & 17 & & UGR & Associate Professor \\
\hline 6 & M & 5 & & UGR & Hired Postdoctoral professor \\
\hline 7 & M & 29 & Pedagogy and singing & $\begin{array}{l}\text { Music superior } \\
\text { school } \\
\text { Conservatory at } \\
\text { Granada }\end{array}$ & $\begin{array}{l}\text { Titular teacher (Special } \\
\text { regimen) }\end{array}$ \\
\hline 8 & M & 23 & $\begin{array}{l}\text { Sports medicine Andalusian } \\
\text { center (CAMD) }\end{array}$ & UGR & Sport doctor \\
\hline 9 & M & 17 & Business organization & UGR & University professor \\
\hline \multirow[t]{2}{*}{10} & $\mathrm{H}$ & 23 & Pedagogy & UGR & Permanent hired doctor \\
\hline & & $\begin{array}{l}25 \text { years: } 1 \\
15 \text { years: } 1\end{array}$ & Pedagogy: 3 & \multirow[t]{2}{*}{ UGR: 8} & $\begin{array}{c}\text { University professor (retired): } 1 \\
\text { University professor: } 3\end{array}$ \\
\hline \multirow[t]{3}{*}{ Total } & $4 \mathrm{H} 6 \mathrm{M}$ & $\begin{array}{l}40 \text { years: } 1 \\
20 \text { years: } 1\end{array}$ & $\begin{array}{l}\text { Business organization: } 2 \\
\text { Traduction and interpretation: } 1\end{array}$ & & $\begin{array}{l}\text { Speaker and Philanthropy: } 1 \\
\text { Associate professor: } 1\end{array}$ \\
\hline & & 17 years: 2 & $\begin{array}{l}\text { Polítical science and } \\
\text { Administration: } 1\end{array}$ & Conservatory: 1 & Titular professor: 1 \\
\hline & & $\begin{array}{l}5 \text { years: } 1 \\
29 \text { years: } 1 \\
23 \text { years: } 2\end{array}$ & $\begin{array}{c}\text { Pedagogy and singing: } 1 \\
\text { CAMD: } 1 \\
\text { Philanthropy and Business: } 1\end{array}$ & Harvard: 1 & $\begin{array}{c}\text { Sport doctor: } 1 \\
\text { Permanent hired doctor: } 1 \\
\text { Hired Postdoctoral professor: } 1\end{array}$ \\
\hline
\end{tabular}

Source: Author's own elaborations.

Therefore, the validation of the content of the unstructured questionnaire has taken into account the assessment made by various experts on different aspects of the questionnaire through the so-called "expert judgement". In addition, another ad hoc questionnaire has been drawn up. The experts were asked to evaluate the semi-structured interview with the items, taking into account the following aspects (see Table 3, validation scale):

- Clarity of content: The questions are clearly and precisely worded, which makes them easy to understand for people suffering for different reasons.

- Clarity of wording: The wording and terminology used are appropriate for the target audience.

- Grouping of questions: Correspondence between the content of the question and the category in which it is placed. Logical order of presentation of questions.

- $\quad$ Relevance of the data provided: The questions are relevant and provide the necessary data to answer the objectives.

- Number of questions: The number of questions, for each of the objectives, is adequate, in a way that the interview does not become too long, in order to avoid interviewees finding it tedious to answer all of the items.

This document provides a guide to validation, structured in two parts:

- Expert's identification data;

- Validation scale. The table below (one is given as an example) refers to the different objectives to which the data collection instrument responds. In this way, the evaluator will be able to assess the questions on each of the 17 categories according to the proposed criteria. In addition, a space is reserved for them to make any recommendations they consider appropriate and to suggest alternative ways of formulating the questions they consider inadequate.

Expert's identification data:

1. Sex: Male ( ) Female ( ) Intergender ( ) Other ( )

2. Years of experience at university:

3. Department to which it belongs

4. Current professional category:

( ) University Professor 
( ) University holder

( ) Permanent Doctoral Candidate

( ) Associate Professor

() Contracted Assistant Doctor

( ) Contracted Assistant

Table 3. Validation scale.

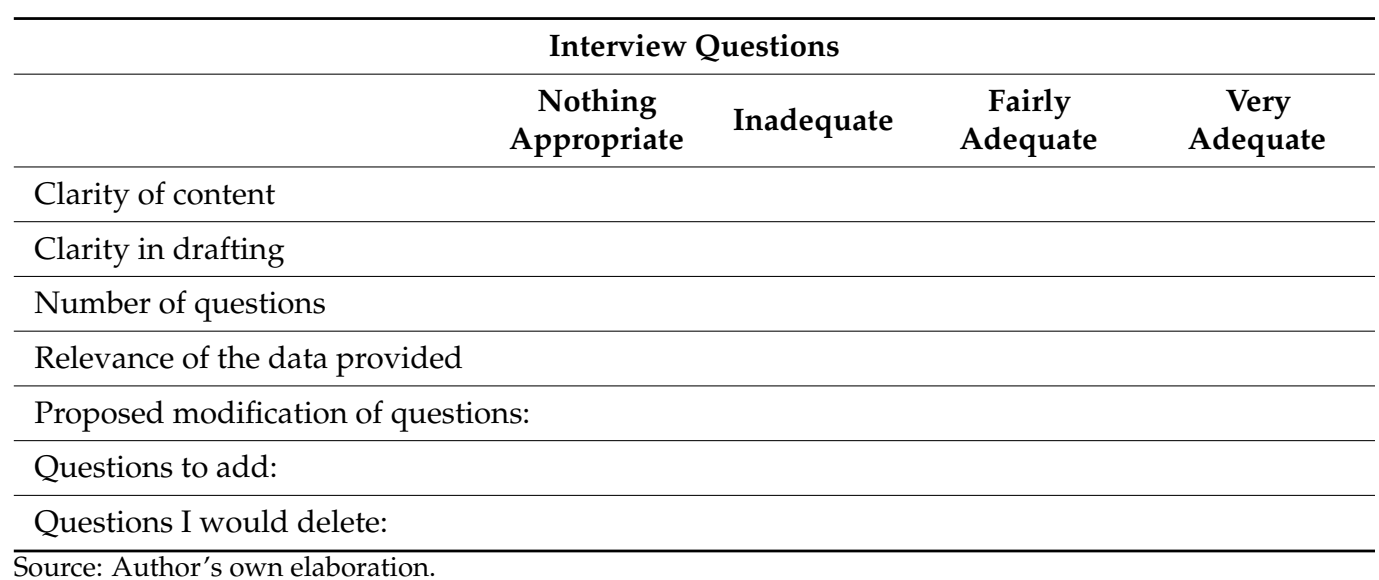

Subsequently, some items of the interview were modified and some recommendations were added, resulting in the final script of the semi-structured interview.

Through this validation scale, the various experts assess a total of 17 different categories (see Table 4), which have emerged as a result of the bibliographic review of the scientific literature that addresses suffering from various fields such as philosophy, psychology, generality, educational sciences, biomedical sciences, etc., since suffering is a phenomenon that must be treated holistically. Through each of these categories, a series of items have been elaborated in order to obtain the information addressed. Similarly, Reference [34] states that there may be room for other items that can be included in the course of the interview in order to delve deeper into the relevant issues that arise.

The 153 questions or items that make up the questionnaire are grouped into these 17 categories. In addition, 10 more items that make up the sample characteristics are included as identification data. These data include attributes such as age, gender, place of residence, ethnicity, level of education, religious affiliation, etc. of future participants who will fill in the unstructured questionnaire, whose object of measurement focuses on trying to measure how people manage suffering due to illness, relationships, economic issues, and lack of adaptation to the environment.

Each of these 17 categories was quantitatively assessed using a Likert scale (from 1: Not suitable at all, through to 4: Very suitable). This quantitative assessment refers to various factors, namely the clarity of the content of the questions and their wording, the adequacy of the number of questions, as well as the relevance of the data provided by the questions. 
Table 4. Categories that make up the instrument and their operational definition.

\begin{tabular}{|c|c|}
\hline Categories & Definition \\
\hline Suffering & $\begin{array}{l}\text { Suffering is a negative emotional response, a complex and negative } \\
\text { affective and cognitive state. It depends on the individual and the } \\
\text { meaning given to it is subject to the fears or challenges it poses for the } \\
\text { person experiencing it. Moreover, it depends on: Mental structure, } \\
\text { flexibility, and adaptability. Optimal care of suffering is based on a } \\
\text { multidimensional and continuous assessment and treatment that } \\
\text { should be carried out in a clinical context where the psychological, } \\
\text { physical, spiritual, and socio-cultural needs of individuals and families } \\
\text { are simultaneously addressed [1]. } \\
\text { Love is the only way to reach the depths of a person's personality. No } \\
\text { one knows the essence of another human being unless he or she loves }\end{array}$ \\
\hline $\begin{array}{l}\text { Love in the } \\
\text { dimension of family, } \\
\text { friends, and partner }\end{array}$ & $\begin{array}{l}\text { him or her. Through the spiritual act of love, the essential traits of the } \\
\text { loved one are seen, their potential, which has not yet been revealed. } \\
\text { Moreover, through love, the one who loves enables the beloved to } \\
\text { realize his or her hidden possibilities. Love enables the other to realize } \\
\text { his or her personal potential [35] (p. 139). }\end{array}$ \\
\hline Acceptance & $\begin{array}{l}\text { the situation, since they have changed their thinking about the } \\
\text { situation instead [6] (p. 326). }\end{array}$ \\
\hline Non-Acceptance & $\begin{array}{l}\text { Psychological problems are not caused by negative thoughts, sadness } \\
\text { or anxiety, but arise when they take on a leading role and end up } \\
\text { becoming relevant and directing the person's choices, pushing the } \\
\text { person's values to the background [36] (p. 16). }\end{array}$ \\
\hline Resignation & $\begin{array}{l}\text { If I resign myself, the pain and suffering will always remain with me, I } \\
\text { remain trapped in the situation I resign myself to, feeling sorry for } \\
\text { myself, feeling that I am a victim of the situation and doing nothing } \\
\text { about it, as I rarely say to myself "this is what it is, I can't do anything } \\
\text { about it".I resign myself [37] (p. 2). }\end{array}$ \\
\hline Spiritual Dimension & $\begin{array}{l}\text { People live their faith (whatever that may be) with faithfulness and } \\
\text { peace, resulting in less stress. This is due to multiple factors: Having } \\
\text { meaning in life, being in a supportive community, purpose and goals } \\
\text { etc., and prayer/meditation as a coping mechanism to deal with } \\
\text { problems and difficulties all contribute to the desired inner balance. } \\
\text { The effects will be similar in Buddhist meditation, in mindfulness, in } \\
\text { Christian prayer, and in Jewish prayer, as long as they involve two } \\
\text { components: Acceptance and surrender. If one asks by demanding, } \\
\text { imploring with anguish, rather than alleviating uneasiness, one } \\
\text { generates more unease [38] (p. 169). }\end{array}$ \\
\hline $\begin{array}{l}\text { Verbal and } \\
\text { non-verbal } \\
\text { communication }\end{array}$ & $\begin{array}{l}\text { Discomfort sets in due to the "game of pretence" that attempts to } \\
\text { maintain the illusion that "everything is fine". This behavior is } \\
\text { detrimental not only to the patient and his or her relatives, but also to } \\
\text { the entire professional team. However, when silence is broken by } \\
\text { dialogue and attentive and sensitive listening, everyone involved is } \\
\text { alleviated. Efficient, respectful, and ethical communication is } \\
\text { fundamental for all at this inevitable time [39] (p. 354). }\end{array}$ \\
\hline Pain & $\begin{array}{l}\text { An objectifiable, unitary, and tipificable sensation, most likely } \\
\text { transmitted by specialized nerve fibers and identified by the patient as } \\
\text { being of this type of sensation, whether pleasant or not [40] (p. 105). }\end{array}$ \\
\hline Fear & $\begin{array}{l}\text { This is a sign that indicates a discrepancy between the threats people } \\
\text { face and the resources they have to resolve them. It is a key emotion for } \\
\text { human survival [41] (p. 90). }\end{array}$ \\
\hline Transience & $\begin{array}{l}\text { The past is a valuable source of information, but it cannot predetermine } \\
\text { a person's future. Dwelling on the past, returning again and again to } \\
\text { something that has already happened, can have harmful effects, } \\
\text { ranging from emotions or sensations such as melancholy, frustration, } \\
\text { guilt, sadness or resentment to depression itself.They all have one thing } \\
\text { in common, which is that they prevent people from enjoying the } \\
\text { present. Remaining mired in the past prevents one from moving } \\
\text { forward in life [38] (p. 66). }\end{array}$ \\
\hline
\end{tabular}


Table 4. Cont.

\begin{tabular}{|c|c|}
\hline Categories & Definition \\
\hline Gratitude & $\begin{array}{l}\text { This is the perception of a positive personal outcome, not necessarily } \\
\text { deserved or earned, due to the actions of another person. It is crediting } \\
\text { someone for positive events. Being grateful has beneficial } \\
\text { consequences, a feeling of recognition towards others or divinity, } \\
\text { which can be expressed in words, objects, and rituals. Whoever gives } \\
\text { thanks expresses gratitude. It is the appreciation one has towards } \\
\text { someone who does a favor or helps. It is a feeling that tries to return } \\
\text { the cooperation received. Gratitude is accompanied by other feelings } \\
\text { such as love, fidelity, and friendship. Gratitude as a value is a virtue } \\
\text { certain individuals show to thank a person who favored them with } \\
\text { their help [17] (p. 42). }\end{array}$ \\
\hline Compassion & $\begin{array}{l}\text { Compassion consists of five elements: Recognizing suffering, } \\
\text { understanding the universality of human suffering, feeling for the } \\
\text { person suffering, tolerating uncomfortable feelings, and motivation to } \\
\text { act to alleviate suffering. It is not only about being touched by a } \\
\text { person's suffering, but also about wanting to act to help that } \\
\text { person [42] (p. 15). }\end{array}$ \\
\hline Hope & $\begin{array}{l}\text { Optimism is related to hope. It consists of knowing the steps that must } \\
\text { be taken to reach a certain goal and having the energy to do so. Hope is } \\
\text { a motivating force, the absence of which leads to paralysis. Hope is } \\
\text { crucial for anyone taking on hard work, and since positive expectations } \\
\text { can be especially beneficial in the most difficult jobs, learning to be } \\
\text { optimistic can be a very rewarding work strategy [43] (p. 184). }\end{array}$ \\
\hline Palliative care & $\begin{array}{l}\text { The aim of palliative care is to prevent and alleviate suffering, and to } \\
\text { provide the best possible quality of life for the sick and their families, } \\
\text { regardless of the stage of the disease or the need for further treatment. } \\
\text { Accompanying a human being who is suffering or dying is one of the } \\
\text { greatest challenges a caregiver can face. Caring is related to respecting } \\
\text { the wishes of the other person, to accepting the other person as they } \\
\text { are, to welcoming their needs, and sharing their anxieties. Caring is } \\
\text { giving oneself in continuous presence, demanding attention and } \\
\text { readiness for communion with the other person. The perception of } \\
\text { their needs involves a degree of sensitivity, of reflection on values, } \\
\text { meanings, and relationships. It demands time, internalization, } \\
\text { openness, and the exercise of respect for others [39] (p. 353). }\end{array}$ \\
\hline Sadness & $\begin{array}{l}\text { Sadness is a negative emotion but it is also useful and evolving. It } \\
\text { arrives when loss of any kind is felt. This emotion regulates grief, it } \\
\text { makes people process it, it makes people take refuge within themselves } \\
\text { until they assimilate it and their strength returns. Its function is to } \\
\text { provide the time and the introspection required to rebuild life without } \\
\text { what has been lost. It makes people feel compassion for themselves } \\
\text { and repair the grief [41] (p. 50). }\end{array}$ \\
\hline Resilience & $\begin{array}{l}\text { Resilience has been defined as "a dynamic developmental process that } \\
\text { reflects evidence of adaptation and effective coping despite significant } \\
\text { life adversity" [44] (p. 8). }\end{array}$ \\
\hline Happiness & $\begin{array}{l}\text { Happiness is not in pain, but in overcoming pain, difficulties, and } \\
\text { obstacles that prevent people from enjoying the authentic essence of } \\
\text { being human [45] (p. 230). }\end{array}$ \\
\hline
\end{tabular}

Source: Author's own elaboration.

Finally, three dimensions of a qualitative nature are also included in the assessment protocol in order for the experts to express how they would modify the questions, if they consider it appropriate, which questions they would add, and which questions they would eliminate. However, this eminently qualitative part is not the subject of analysis and discussion in this paper. 


\subsection{Procedure and Statistics}

For the validation of the content of the unstructured questionnaire, the purpose of which is to measure how people manage their level of suffering due to illness, relationships, economic issues, and failure to adapt to the environment, two different but complementary strategies have been considered.

On the one hand, the content validity of each of the 17 dimensions of the questionnaire was calculated individually in relation to the four dimensions considered. For this purpose, Aiken's V validity coefficient was calculated up to 68 times $(17 \times 4)[46,47]$. This index is useful for evaluating the importance of each item with respect to the construct being assessed. Its main advantage over similar indices, for example, [48], "is that it takes into account not only the number of categories available to the experts, but also the number of participating experts" [49] (p. 11).

Notwithstanding the above, the interpretation of this index was somewhat imprecise, since it was not associated with any statistical probability (p), nor with any confidence interval. For this reason, Reference [50] proposed a new reformulation of Aiken's index based on the following terms:

$$
V=\frac{\mu-l}{k}
$$

where $\bar{X}$ is the average of the judges' ratings; $l$ is the lowest obtainable score possible $(1$, in this case); and $k$ is the difference between the highest and lowest score on the rating scale completed by the various experts (ranging from 1 to 4 points, as shown above, therefore $k=3$ in this particular case).

For a meaningful interpretation of the same, Reference [50] adopted the so-called score method, whose advantage lies in its precision, despite the fact that the distribution here is asymmetric in nature. Moreover, these authors consider the Aiken index as a ratio to establish the interval at a given confidence level [51]. The equations for lower (L) and upper $(\mathrm{U})$ confidence intervals are as follows:

$$
\begin{aligned}
& L=\frac{2 n k V+z^{2}-z \sqrt{4 n k V(1-V)+z^{2}}}{2\left(n k+z^{2}\right)} \\
& U=\frac{2 n k V+z^{2}-z \sqrt{4 n k V(1-V)+z^{2}}}{2\left(n k+z^{2}\right)}
\end{aligned}
$$

where $L$ is the lower bound and $U$, the upper bound; $n$ is the number of judges; $k$ is the difference between the highest and lowest score on the rating scale; $V$ is the value of Aiken's $\mathrm{V}$; and $z$ is the chosen standard distribution. Therefore, $90 \%, 95 \%$, and $99 \%$ confidence corresponds to $1.65,1.96$, and 2.58 , respectively.

For the interpretation of confidence intervals, it is recommended that the lower limit should have a value $\geq 0.7$ [52], although it is known that the confidence interval amplitude is highly dependent on the increase in sample size [50].

Furthermore, the need to take into account a global index of each of the dimensions of the four dimensions as a whole, i.e., globally, was considered. For this purpose, the most precise coefficient for this type of condition has been calculated, i.e., the intraclass correlation coefficient.

\section{Results}

Once the opinions of the 10 experts had been collected, two data matrices were drawn up with all of the information. The first matrix with an .xls extension is used to calculate the content validity of the 17 dimensions of the questionnaire considered (suffering, love, acceptance, etc.) in relation to the four aspects considered (content, wording, number, and relevance of the items). The second matrix with an SPSS sav extension is used to calculate the agreement between the different experts measured on a metric scale (interval scale), for each of the four aspects considered (content, wording, number, and relevance of the items). 
Therefore, from the first matrix, which has the Excel .xls extension, the Aiken V content validity index for each of the 17 dimensions in four differential aspects was calculated $(17 \times 4=68)$ (see Table 5). For this purpose, the application of [53] was used. The results obtained in this respect are shown below.

Table 5. Results and interpretation of the content validity calculated using Aiken's V.

\begin{tabular}{|c|c|c|c|c|c|c|c|}
\hline \multirow[b]{2}{*}{$\begin{array}{l}\text { Dimensions of Scale and } \\
\text { Criteria Considered }\end{array}$} & \multirow[b]{2}{*}{$\begin{array}{l}\text { Number of } \\
\text { Reviewers }\end{array}$} & \multirow[b]{2}{*}{ Mean } & \multirow[b]{2}{*}{ Sd } & \multirow[b]{2}{*}{$\begin{array}{l}\text { Aiken V } \\
\text { Index }\end{array}$} & \multirow[b]{2}{*}{ Interp. } & \multicolumn{2}{|c|}{ 95\% Confidence Interval } \\
\hline & & & & & & $\begin{array}{l}\text { Lower } \\
\text { Bound }\end{array}$ & $\begin{array}{l}\text { Upper } \\
\text { Bound }\end{array}$ \\
\hline suf_cont & 10 & 3.30 & 0.82 & 0.77 & Valid & 0.59 & 0.88 \\
\hline suf_draftr & 10 & 2.80 & 0.79 & 0.60 & Not valid & 0.42 & 0.75 \\
\hline suf_number & 10 & 2.70 & 0.95 & 0.57 & Not valid & 0.39 & 0.73 \\
\hline suf_relev & 10 & 3.40 & 0.70 & 0.80 & Valid & 0.63 & 0.90 \\
\hline love_cont & 10 & 3.40 & 0.70 & 0.80 & Valid & 0.63 & 0.90 \\
\hline love_draftr & 10 & 3.40 & 0.52 & 0.80 & Valid & 0.63 & 0.90 \\
\hline love_number & 10 & 2.90 & 0.88 & 0.63 & Not valid & 0.46 & 0.78 \\
\hline love_relev & 10 & 3.20 & 0.92 & 0.73 & Valid & 0.56 & 0.86 \\
\hline accep_cont & 10 & 3.30 & 0.67 & 0.77 & Valid & 0.59 & 0.88 \\
\hline accep_draftr & 10 & 3.20 & 0.63 & 0.73 & Valid & 0.56 & 0.86 \\
\hline accep_number & 10 & 3.30 & 0.67 & 0.77 & Valid & 0.59 & 0.88 \\
\hline accep_relev & 10 & 3.40 & 0.52 & 0.80 & Valid & 0.63 & 0.90 \\
\hline no_accept_cont & 10 & 3.10 & 0.88 & 0.70 & Valid & 0.52 & 0.83 \\
\hline no_accept_draftr & 10 & 3.20 & 0.63 & 0.73 & Valid & 0.56 & 0.86 \\
\hline no_accept_number & 10 & 3.20 & 0.63 & 0.73 & Valid & 0.56 & 0.86 \\
\hline no_accept_relev & 10 & 2.90 & 0.88 & 0.63 & Not valid & 0.46 & 0.78 \\
\hline resig_cont & 10 & 3.40 & 0.52 & 0.80 & Valid & 0.63 & 0.90 \\
\hline resig_draftr & 10 & 3.50 & 0.53 & 0.83 & Valid & 0.66 & 0.93 \\
\hline resig_number & 10 & 3.50 & 0.53 & 0.83 & Valid & 0.66 & 0.93 \\
\hline resig_relev & 10 & 3.40 & 0.52 & 0.80 & Valid & 0.63 & 0.90 \\
\hline spirt_cont & 10 & 3.22 & 0.67 & 0.74 & Valid & 0.56 & 0.86 \\
\hline spirt_draftr & 10 & 2.90 & 0.74 & 0.63 & Not valid & 0.46 & 0.78 \\
\hline spirt_number & 10 & 3.20 & 0.63 & 0.73 & Valid & 0.56 & 0.86 \\
\hline spirt_relev & 10 & 3.30 & 0.48 & 0.77 & Valid & 0.59 & 0.88 \\
\hline verb_noverb_comm_cont & 10 & 3.50 & 0.53 & 0.83 & Valid & 0.66 & 0.93 \\
\hline verb_noverb_comm_draftr & 10 & 3.40 & 0.52 & 0.80 & Valid & 0.63 & 0.90 \\
\hline verb_noverb_comm_number & 10 & 3.10 & 0.74 & 0.70 & Valid & 0.52 & 0.83 \\
\hline verb_noverb_comm_relev & 10 & 3.50 & 0.53 & 0.83 & Valid & 0.66 & 0.93 \\
\hline pain_cont & 10 & 3.40 & 0.52 & 0.80 & Valid & 0.63 & 0.90 \\
\hline pain_draftr & 10 & 3.10 & 0.74 & 0.70 & Valid & 0.52 & 0.83 \\
\hline pain_number & 10 & 3.30 & 0.67 & 0.77 & Valid & 0.59 & 0.88 \\
\hline pointrel & 10 & 3.40 & 0.52 & 0.80 & Valid & 0.63 & 0.90 \\
\hline fear_cont & 10 & 3.20 & 0.63 & 0.73 & Valid & 0.56 & 0.86 \\
\hline fear_draftr & 10 & 3.20 & 0.63 & 0.73 & Valid & 0.56 & 0.86 \\
\hline fear_number & 10 & 3.40 & 0.52 & 0.80 & Valid & 0.63 & 0.90 \\
\hline fear_relev & 10 & 3.40 & 0.52 & 0.80 & Valid & 0.63 & 0.90 \\
\hline
\end{tabular}


Table 5. Cont.

\begin{tabular}{|c|c|c|c|c|c|c|c|}
\hline \multirow[b]{2}{*}{$\begin{array}{l}\text { Dimensions of Scale and } \\
\text { Criteria Considered }\end{array}$} & \multirow[b]{2}{*}{$\begin{array}{l}\text { Number of } \\
\text { Reviewers }\end{array}$} & \multirow[b]{2}{*}{ Mean } & \multirow[b]{2}{*}{ Sd } & \multirow[b]{2}{*}{$\begin{array}{l}\text { Aiken V } \\
\text { Index }\end{array}$} & \multirow[b]{2}{*}{ Interp. } & \multicolumn{2}{|c|}{$95 \%$ Confidence Interva } \\
\hline & & & & & & $\begin{array}{l}\text { Lower } \\
\text { Bound }\end{array}$ & $\begin{array}{l}\text { Upper } \\
\text { Bound }\end{array}$ \\
\hline trans_cont & 10 & 3.30 & 0.67 & 0.77 & Valid & 0.59 & 0.88 \\
\hline trans_draftr & 10 & 3.30 & 0.67 & 0.77 & Valid & 0.59 & 0.88 \\
\hline trans_number & 10 & 3.50 & 0.53 & 0.83 & Valid & 0.66 & 0.93 \\
\hline trans_relev & 10 & 3.50 & 0.53 & 0.83 & Valid & 0.66 & 0.93 \\
\hline grat_cont & 10 & 3.30 & 0.48 & 0.77 & Valid & 0.59 & 0.88 \\
\hline grat_draftr & 10 & 3.00 & 0.82 & 0.67 & Not valid & 0.49 & 0.81 \\
\hline grat_number & 10 & 3.30 & 0.48 & 0.77 & Valid & 0.59 & 0.88 \\
\hline grat_relev & 10 & 3.30 & 0.48 & 0.77 & Valid & 0.59 & 0.88 \\
\hline comp_cont & 10 & 3.20 & 0.63 & 0.73 & Valid & 0.56 & 0.86 \\
\hline comp_draftr & 10 & 3.20 & 0.63 & 0.73 & Valid & 0.56 & 0.86 \\
\hline comp_number & 10 & 3.20 & 0.92 & 0.73 & Valid & 0.56 & 0.86 \\
\hline comp_relev & 10 & 3.20 & 0.63 & 0.73 & Valid & 0.56 & 0.86 \\
\hline hope_cont & 10 & 3.20 & 0.42 & 0.73 & Valid & 0.56 & 0.86 \\
\hline hope_draftr & 10 & 3.30 & 0.48 & 0.77 & Valid & 0.59 & 0.88 \\
\hline hope_number & 10 & 3.20 & 0.42 & 0.73 & Valid & 0.56 & 0.86 \\
\hline hope_relev & 10 & 3.30 & 0.48 & 0.77 & Valid & 0.59 & 0.88 \\
\hline palliat_care_cont & 10 & 3.40 & 0.52 & 0.80 & Valid & 0.63 & 0.90 \\
\hline palliat_care_draftr & 10 & 3.40 & 0.52 & 0.80 & Valid & 0.63 & 0.90 \\
\hline palliat_care_number & 10 & 3.30 & 0.67 & 0.77 & Valid & 0.59 & 0.88 \\
\hline palliat_care_relev & 10 & 3.40 & 0.52 & 0.80 & Valid & 0.63 & 0.90 \\
\hline sadness_cont & 10 & 3.40 & 0.52 & 0.80 & Valid & 0.63 & 0.90 \\
\hline sadness_draftr & 10 & 3.40 & 0.52 & 0.80 & Valid & 0.63 & 0.90 \\
\hline sadness_number & 10 & 3.30 & 0.82 & 0.77 & Valid & 0.59 & 0.88 \\
\hline sadness_relev & 10 & 2.80 & 0.79 & 0.60 & Not valid & 0.42 & 0.75 \\
\hline resil_cont & 10 & 2.70 & 0.95 & 0.57 & Not valid & 0.39 & 0.73 \\
\hline resil_draftr & 10 & 3.40 & 0.70 & 0.80 & Valid & 0.63 & 0.90 \\
\hline resil_number & 10 & 3.40 & 0.70 & 0.80 & Valid & 0.63 & 0.90 \\
\hline resil_relev & 10 & 3.40 & 0.52 & 0.80 & Valid & 0.63 & 0.90 \\
\hline happiness_cont & 10 & 2.90 & 0.88 & 0.63 & Not valid & 0.46 & 0.78 \\
\hline happiness_draftr & 10 & 3.20 & 0.92 & 0.73 & Valid & 0.56 & 0.86 \\
\hline happiness_number & 10 & 3.30 & 0.67 & 0.77 & Valid & 0.59 & 0.88 \\
\hline happinees_relev & 10 & 3.20 & 0.63 & 0.73 & Valid & 0.56 & 0.86 \\
\hline
\end{tabular}

As can be seen, the content validity values obtained in the 68 dimensions assessed are, in general, satisfactory (they are worthy of content validity), if considering as a cut-off point that any Aiken V value $>0.70$ can be considered adequate [54]. It is no less true in this respect, that out of the 68 dimensions assessed, nine did not exceed the minimum value for content validity, all with arithmetic means $<3$ and with larger standard deviations (greater heterogeneity in the scores of the experts) than the remaining 59, which have arithmetic means $>3$ and smaller standard deviations denoting less heterogeneity in the experts' scoring. For this reason, it is necessary to modify the items that make up these dimensions 
with the additional incorporation of the qualitative suggestions for improvement indicated by the experts.

In relation to the concordance or level of agreement reached among the experts, the intraclass correlation coefficient was developed (see Table 6). This coefficient is a robust technique based on repeated measures or within-subject variance analysis [55].

In this sense, the starting point is a data matrix of order $n x k$, where $n$ in this case is the various aspects evaluated and $k$ is the evaluators, containing each evaluation $X_{i j}$ of the evaluated aspect (i) by each evaluator ( $j$ ). To determine the intraclass correlation coefficient, the different sources of variation (resources of variation), i.e., the various sums of squares $\rightarrow S S_{s u j}$ : Variation between the rated aspects; $S S_{\text {eval }}$ : Variation between the experts, and $S S_{\text {res }}$ : Error or residual variation, must be broken down. Taking into account the results referred to in the variance analysis, as well as the formula for the development of the intraclass correlation coefficient for a two-way mixed effects model where people effects are random and measures effects are fixed, i.e.,

$$
I C C=\frac{M S_{\text {suj }}-M S_{\text {res }}}{M S_{\text {suj }}+(k-1) M S_{\text {res }}+k / n\left(M S_{\text {eval }}-M S_{\text {res }}\right)}
$$

where $M S_{s u j}$ represents the mean square of the rated aspects; $M S_{\text {eval }}$ represents the mean square of the experts' ratings, and $M S_{\text {res }}$ represents the mean square of the error or residual.

Table 6. Results of the absolute agreement between experts calculated using the intraclass correlation coefficient.

\begin{tabular}{|c|c|c|c|c|c|c|c|c|}
\hline \multirow{4}{*}{ Total (four dimensions) } & \multirow[b]{2}{*}{$\begin{array}{l}\text { Measure } \\
\text { Type }\end{array}$} & \multirow[b]{2}{*}{$\begin{array}{c}\text { Intraclass } \\
\text { Correlation }\end{array}$} & \multicolumn{2}{|c|}{ 95\% Confidence Interval } & \multicolumn{4}{|c|}{ F Test with True Value 0} \\
\hline & & & $\begin{array}{l}\text { Lower } \\
\text { Bound }\end{array}$ & $\begin{array}{l}\text { Upper } \\
\text { Bound }\end{array}$ & Value & df1 & df2 & Sig. \\
\hline & $\begin{array}{l}\text { Single } \\
\text { Measures }\end{array}$ & $0.627^{\mathrm{a}}$ & 0.429 & 0.862 & 115.370 & 8 & 536 & $0 * * *$ \\
\hline & $\begin{array}{l}\text { Average } \\
\text { Measures }\end{array}$ & $0.991^{\mathrm{c}}$ & 0.981 & 0.998 & 115.370 & 8 & 536 & $0 * * *$ \\
\hline \multirow{4}{*}{ Content of items } & \multirow[b]{2}{*}{$\begin{array}{l}\text { Measure } \\
\text { Type }\end{array}$} & \multirow[b]{2}{*}{$\begin{array}{c}\text { Intraclass } \\
\text { Correlation }\end{array}$} & \multicolumn{2}{|c|}{ 95\% Confidence Interval } & \multicolumn{4}{|c|}{ F Test with True Value 0} \\
\hline & & & $\begin{array}{l}\text { Lower } \\
\text { Bound }\end{array}$ & $\begin{array}{l}\text { Upper } \\
\text { Bound }\end{array}$ & Value & df1 & df2 & Sig. \\
\hline & $\begin{array}{c}\text { Single } \\
\text { Measures }\end{array}$ & $0.624^{a}$ & 0.409 & 0.864 & 29.273 & 8 & 128 & $0^{* * *}$ \\
\hline & $\begin{array}{c}\text { Average } \\
\text { Measures }\end{array}$ & $0.966^{c}$ & 0.922 & 0.991 & 29.273 & 8 & 128 & $0 * * *$ \\
\hline \multirow{4}{*}{ Drafting of items } & \multirow{2}{*}{$\begin{array}{c}\text { Measure } \\
\text { Type }\end{array}$} & \multirow[b]{2}{*}{$\begin{array}{l}\text { Intraclass } \\
\text { Correlation }\end{array}$} & \multicolumn{2}{|c|}{ 95\% Confidence Interval } & \multicolumn{4}{|c|}{ F Test with True Value 0} \\
\hline & & & $\begin{array}{l}\text { Lower } \\
\text { Bound }\end{array}$ & $\begin{array}{l}\text { Upper } \\
\text { Bound }\end{array}$ & Value & df1 & df2 & Sig. \\
\hline & $\begin{array}{c}\text { Single } \\
\text { Measures }\end{array}$ & $0.609^{a}$ & 0.402 & 0.844 & 27.428 & 9 & 144 & $0 * * *$ \\
\hline & $\begin{array}{l}\text { Average } \\
\text { Measures }\end{array}$ & $0.964^{\mathrm{c}}$ & 0.92 & 0.989 & 27.428 & 9 & 144 & $0^{* * *}$ \\
\hline \multirow{4}{*}{$\begin{array}{l}\text { Appropriateness of Number } \\
\text { of items }\end{array}$} & \multirow[b]{2}{*}{$\begin{array}{l}\text { Measure } \\
\text { Type }\end{array}$} & \multirow[b]{2}{*}{$\begin{array}{c}\text { Intraclass } \\
\text { Correlation }\end{array}$} & \multicolumn{2}{|c|}{ 95\% Confidence Interval } & \multicolumn{4}{|c|}{ F Test with True Value 0} \\
\hline & & & $\begin{array}{l}\text { Lower } \\
\text { Bound }\end{array}$ & $\begin{array}{l}\text { Upper } \\
\text { Bound }\end{array}$ & Value & df1 & df2 & Sig. \\
\hline & $\begin{array}{c}\text { Single } \\
\text { Measures }\end{array}$ & $0.595^{a}$ & 0.388 & 0.836 & 25.929 & 9 & 144 & $0 * * *$ \\
\hline & $\begin{array}{l}\text { Average } \\
\text { Measures }\end{array}$ & $0.961^{\mathrm{c}}$ & 0.915 & 0.989 & 25.929 & 9 & 144 & $0 * * *$ \\
\hline \multirow{4}{*}{ Relevance of items } & \multirow{2}{*}{$\begin{array}{l}\text { Measure } \\
\text { Type }\end{array}$} & \multirow{2}{*}{$\begin{array}{l}\text { Intraclass } \\
\text { Correlation }\end{array}$} & \multicolumn{2}{|c|}{ 95\% Confidence Interval } & \multicolumn{4}{|c|}{ F Test with True Value 0} \\
\hline & & & $\begin{array}{l}\text { Lower } \\
\text { Bound }\end{array}$ & $\begin{array}{l}\text { Upper } \\
\text { Bound }\end{array}$ & Value & df1 & df2 & Sig. \\
\hline & $\begin{array}{c}\text { Single } \\
\text { Measures }\end{array}$ & $0.641^{\mathrm{a}}$ & 0.437 & 0.860 & 31.290 & 9 & 144 & $0 * * *$ \\
\hline & $\begin{array}{l}\text { Average } \\
\text { Measures }\end{array}$ & $0.968^{c}$ & 0.93 & 0.991 & 31.290 & 9 & 144 & $0^{* * *}$ \\
\hline
\end{tabular}

Two-way mixed effects model where people effects are random and measure effects are fixed. ${ }^{a}$ The estimator is the same whether the interaction effects is present or not. ${ }^{b}$ Type a intraclass correlation coefficients using an absolute agreement definition. ${ }^{\mathrm{c}}$ This estimate is computed assuming that the interaction effect is absent, since it is not estimable otherwise. ${ }^{* * *} p<0.001$. Source: Author's own elaboration. 
As can be seen from the table above, in all of the cases the intraclass correlation coefficients (ICC) obtained refer to the single measures as an absolute agreement, as those referring to the average measure are in fact Cronbach's $\alpha$ coefficients (consistency).

Moreover, it can be seen that the results obtained range from the smallest value for the appropriateness of the number of items $\mathrm{CCI}=0.595$ and the largest value of $\mathrm{CCI}=0.641$ referring to the relevance of the items. In any case, and taking into consideration the interpretative criteria of [55-57], the values obtained can be considered to be moderately agreed among the 10 experts. On the other hand, the significance values associated with each coefficient (all $p<0.001)$ reveal that the agreements, moreover, are not due to chance.

\section{Conclusions of the Study}

The management of people's suffering due to illness, relationships, economic issues, and failure to adapt to the environment is a complex issue. It was not sufficient to define each of the categories with scientific literature, but they have also been properly quantified. In recent times, qualitative methodology has been strengthened as a procedure for obtaining scientific knowledge and limiting factors, such as the treatment of validity or the incorporation of computer programs, have been resolved.

Qualitative research is the scientific method of observation to collect non-numerical data. Instruments for measuring distress include interviews, surveys, focus groups, observation techniques, and participant observation. Qualitative research is based on case studies, personal experiences, life stories, interviews, etc. Therefore, this research does not insist on a representative sample of results. It acquires external validity through various strategies, including fieldwork and triangulation of results. Methodologically, it is an interpretative, naturalistic approach to its object of study. This means understanding reality in its natural and everyday context, trying to interpret the phenomena according to the meanings given to it by the people involved, since descriptive data are obtained such as the interviewees' own spoken or written expressions, observable behavior, culture, and religion.

It is assumed that the information provided by qualitative techniques is just as useful and scientific as quantitative techniques. The difference lies in the type of information that each one provides. Furthermore, it should be borne in mind that there is no single form of qualitative research, but rather multiple approaches whose fundamental differences are marked by the choices made [58], and thus the use of the most appropriate techniques for collecting information.

The qualitative technique in our case is the one that has been developed, characterized by a deductive-inductive process through interviews that have brought the researcher closer to the knowledge of suffering and its management. Moreover, it provides us with a greater depth in the response and a greater understanding of the phenomenon under study. Furthermore, the interviews allow for more flexibility in their application and favor the establishment of a more direct link with the subjects.

Among the advantages provided by qualitative techniques, the following are highlighted:

- They address complex problems such as the study of the management of suffering, beliefs, motivations, and attitudes of the population. Personal suffering is very difficult to measure, in the same way as it is difficult to measure the des humanization of human beings;

- They allow for the participation of individuals with diverse experiences, which provides a broader view of the problems;

- A large number of ideas are generated quickly, and decision-making time is reduced.

In this piece of research, the interview was carried out, as has been seen, since it possesses suitable characteristics such as: Understanding rather than explaining, the expected answers are subjective and sincere, the interviewer listens but does not evaluate, there is maximum flexibility, as new topics arise, they are addressed, contextualized information is obtained, and there are open answers without pre-established categories, etc. 
The information collected in the semi-structured interviews is of high quality, confidential, and complex. Therefore, it has an acceptable content validity for use to the extent of the criterion under consideration.

In relation to validation of the content of the questionnaire, it should be noted that, in general, a moderate relevance of each item with respect to the evaluated construct has been achieved, as can be seen from the various validity indices calculated for the different dimensions and criteria considered. In terms of agreement among the experts, moderately high intraclass correlation coefficients (ICC) were also achieved, which, more importantly, were statistically significant and, therefore, not due to chance. Notwithstanding the above, there are some considerations to be taken into account.

With regards to content validity, not all of the dimensions assessed obtained similar results. In this respect, it can be seen that the suffering dimension is that which, after the experts' assessment, did not obtain sufficiently high validity coefficients in relation to the wording and adequate number of items. This is why it is necessary to reformulate the items that make up this dimension on the basis of the considerations suggested by the experts.

Other dimensions that also failed to achieve minimally adequate content validity indices were the dimensions love (adequate number of items), non-acceptance (relevance), spirituality (wording), gratitude (wording), sadness (relevance), resilience (content), and happiness (content). In addition to content validity, expert agreement has been considered for this study. In this sense, results were recorded that show that the degree of agreement among the experts is moderately high and, moreover, is not due to chance. Although as in the case of content validity, some dimensions achieved more agreement than others. The dimension with the greatest agreement is the relevance of the items that make up the questionnaire, while that which generated the least agreement, although sufficient, was the number of items that make up the questionnaire, which is considered as excessively high by the experts and whose findings call for reduction. For all of these reasons, and taking into consideration the suggestions for improvement made by the experts, the items of these dimensions in the aspects explained have been reformulated based on the experts' findings, which the reader can consult as an appendix to this work.

Therefore, the experience accumulated in qualitative research cannot go unnoticed even by those who opt for epistemological positions close to the most orthodox positivism, which is to say, to that closed vision that exclusively seeks to find objectivity in what can be quantified and reduced to the merely statistical.

This article is an example of this, in which an attempt has been made to make up for the possible shortcomings of the qualitative method, using the so-called expert judgement and Aiken's V coefficient for content validation, although improvement is always a work in progress, since expressing reality and producing knowledge is done through a dialectic process in which there is the art of persuading, debating, and reasoning different ideas in order to try to arrive at the truth.

From this point of view, relevant information is represented in order to validate the researcher's action, which is focused on a hermeneutic rationality expressed in qualitative methods. Field information has been collected in an organized way with the construction of a priori categories, appropriate procedures have been used to analyze the information obtained from the judgement of experts, and criteria to interpret this information with the aim of providing a suitable tool to those who work in education under this perspective.

Finally, with regards to future projections, there is still a lot of work to be done. In this continuous learning process, strategies for action must be designed in context and integrated where the actors are protagonists and agents. Moreover, we understand that this must be carried out from a multidisciplinary approach that incorporates and integrates everything that has been researched in different fields. These strategies must go a step further and be implemented in the management of different areas (social, clinical, educational). It is a question of understanding in order to be able to act.

Author Contributions: Investigation, C.S.-G.P., E.M.A.R., and C.R.-S. Conceptualization, C.S.-G.P.; methodology, E.M.A.R.; software, C.R.-S.; validation, E.M.A.R., and C.S.-G.P.; formal analysis, 
E.M.A.R.; investigation, C.R.-S.; resources, C.S.-G.P.; data curation, C.S.-G.P.; writing-original draft preparation, C.S.-G.P.; writing-review and editing, E.M.A.R., and C.R.-S.; visualization, E.M.A.R., and C.R.-S.; supervision, E.M.A.R., and C.R.-S. ; project administration, C.S.-G.P., E.M.A.R., and C.R.-S. funding acquisition, C.S.-G.P., E.M.A.R., and C.R.-S. All authors have read and agreed to the published version of the manuscript.

Funding: This research received no external funding.

Institutional Review Board Statement: This study has SAER coordinator Review Statement (DNI 24212682F).

Informed Consent Statement: Written informed consent was obtained from the informants involved in the study.

Data Availability Statement: The datasets generated and / or analyzed during the current study will not be publicly available due to privacy and confidentiality reasons, but they will be available from the corresponding author upon reasonable request.

Conflicts of Interest: The authors declare no conflict of interest.

\section{Appendix A}

Table A1. Semi-structured interview "the management of suffering in people suffering from illness, relationships, economic problems, and adaptation to the environment".

\begin{tabular}{|c|c|c|}
\hline Categories & Initial Items & Final Items \\
\hline Suffering & $\begin{array}{l}\text { 1. Do you feel that you are suffering? } \\
\text { 2. } \quad \text { For what reason are you suffering? } \\
\text { 3. Have you suffered in your life for reasons } \\
\text { other than this one? } \\
\text { 4. Can you describe your suffering? } \\
\text { 5. Did you experience difficult situations before } \\
\text { this problem occurred? } \\
\text { 6. Are there any differences between how you } \\
\text { dealt with the previous problem and this one? } \\
\text { 7. Do you think that going through periods of } \\
\text { suffering would facilitate resurgence, change } \\
\text { or evolution in people? } \\
\text { 8. What has helped you reduce your suffering? } \\
\text { 9. Have you used any therapy, exercises, tools, } \\
\text { 10. Is suffering inherent in human nature? } \\
\text { 11. Could the origin of suffering be selfishness? } \\
\text { 12. Does one choose to suffer? } \\
\text { 13. Does suffering make you look for what you are } \\
\text { missing? } \\
\text { 14. Is suffering a warning sign that we should } \\
\text { change something? } \\
\text { 15. Is suffering necessary for learning? } \\
\text { 16. Is suffering the consequence of having } \\
\text { committed irresponsible acts or misbehaving? } \\
\text { 17. Who causes suffering? } \\
\text { 18. Does suffering make sense? } \\
\text { 19. Does suffering make you change, evolve? } \\
\text { 20. Does suffering help you see life differently? } \\
\text { 21. Can human beings make sense of suffering? } \\
\text { 22. What is your level of suffering? Low, } \\
\text { intermediate, high? } \\
\text { 23. Is suffering a consequence of } \\
\text { non-understanding and non-acceptance? }\end{array}$ & $\begin{array}{l}\text { 1. What is suffering for you, could you describe it? } \\
\text { 2. Are you suffering, do you consider that in some } \\
\text { 3. Fores suffering is a choice? } \\
\text { 4. Have you tried any therapy, exercises, tools, } \\
\text { 5. Have you asked someone for help in order to } \\
\text { eliminate suffering? } \\
\text { 6. Does suffering make sense? } \\
\text { 7. Could identifying with the problem be a reason for } \\
\text { 8. Is suffering? } \\
\text { 9. Irresponsible acts or having behaved unethically? } \\
\text { Do you think that suffering is a positive state for } \\
\text { human beings to survive and to become more } \\
\text { ethical? }\end{array}$ \\
\hline
\end{tabular}


Table A1. Cont.

\begin{tabular}{|c|c|c|}
\hline Categories & Initial Items & Final Items \\
\hline $\begin{array}{l}\text { Love in the } \\
\text { dimension of } \\
\text { family, friends, } \\
\text { and partner }\end{array}$ & $\begin{array}{l}\text { 24. What is your name? } \\
\text { 25. Where were you born? } \\
\text { 26. Where are you from? } \\
\text { 27. How old are you? } \\
\text { 28. What did you study? } \\
\text { 29. What did you do for a living? } \\
\text { 30. What did your parents do for a living? } \\
\text { 31. Where and with whom did you live when you } \\
\text { 32. Dere a child? } \\
\text { grandchildren or anyone else you feel is your } \\
\text { family? } \\
\text { 34. Do suffering and love go together? } \\
\text { 35. Did your family help you grow and mature? } \\
\text { For example, mutual commitment and } \\
\text { dedication. Gratitude and ability to cope with } \\
\text { 36. Droblems. }\end{array}$ & $\begin{array}{l}\text { 1. How would you define love and what does it } \\
\text { 2. } \begin{array}{l}\text { Dean to you? } \\
\text { grandchildren or anyone else you feel is your } \\
\text { family? }\end{array} \\
\text { 3. Do you feel abandoned or loved by your family } \\
\text { now and in the past, tell me by whom? } \\
\text { 4. Do you need to be loved? } \\
\text { 5. How do you feel when you are rejected by } \\
\text { someone you love such as your parents, siblings, } \\
\text { friends, etc? How do you act in these situations? } \\
\text { 6. How do you feel about giving your best when you } \\
\text { have been rejected? } \\
\text { 7. What is unconditional love for you and towards } \\
\text { w. Dhom do you feel it? } \\
\text { 9. Did your family help you grow and mature? } \\
\text { 10. What do friends bring to one's life? What have } \\
\text { they brought to your life? } \\
\text { 11. What do relationships bring to one's life? What } \\
\text { have they brought to your life? } \\
\text { 12. Who do you turn to when you feel bad? } \\
\text { 13. Is it bad to be alone, do you suffer more or less? } \\
\text { Why? } \\
\text { 14. Do you maintain constant and deep ties with your } \\
\text { family members nowadays? How would you } \\
\text { define them? What do these ties bring you? }\end{array}$ \\
\hline Acceptance & $\begin{array}{l}\text { 37. Do you accept what is happening to you and } \\
\text { why? } \\
\text { 38. Are you happy with your new situation? } \\
\text { 39. Does acceptance make you discover, reinforce } \\
\text { and prioritize your thoughts, positive } \\
\text { behaviors, valuable actions, and values in your } \\
\text { life? } \\
\text { 40. If you accept, do you feel better and have more } \\
\text { vital energy to resolve the situation and relate } \\
\text { to others? }\end{array}$ & $\begin{array}{l}\text { 1. What is acceptance for you? } \\
\text { 2. Do you accept others? Who and in what way? } \\
\text { 3. Do you feel at peace or calm or not with the } \\
\text { situation you are living in, in terms of what you } \\
\text { have to "face at this moment, acknowledge what is } \\
\text { happening to you" and that it is better to } \\
\text { assimilate it? Why? } \\
\text { 4. If you end up acknowledging what is happening } \\
\text { to you, how would you feel? } \\
\text { 5. If you accepted it, would you be more motivated } \\
\text { to resolve the situation and relate to others? }\end{array}$ \\
\hline $\begin{array}{c}\text { Non- } \\
\text { Acceptance }\end{array}$ & $\begin{array}{l}\text { 41. Do you suffer? } \\
\text { 42. For what reasons do you suffer or what reasons } \\
\text { prevent you from accepting your situation? } \\
\text { 43. What do you see as the opposite of suffering? } \\
\text { 44. How can you prevent yourself from suffering } \\
\text { due to what you are experiencing? }\end{array}$ & $\begin{array}{l}\text { 1. For what reasons do you suffer? } \\
\text { 2. What reasons prevent you from accepting the } \\
\text { present situation that is making you suffer? } \\
\text { 3. What do you think you would feel if you were } \\
\text { able to accept your current situation? } \\
\text { 4. What do you feel when you do not accept adverse } \\
\text { 5. How can non-acceptance influence you? } \\
\text { 6. To what extent does not accepting what is } \\
\text { happening to you contribute to increasing your } \\
\text { degree of suffering? }\end{array}$ \\
\hline
\end{tabular}


Table A1. Cont.

\begin{tabular}{|c|c|c|c|c|}
\hline Categories & & Initial Items & & Final Items \\
\hline Resignation & $\begin{array}{l}45 . \\
46 . \\
47 . \\
48 .\end{array}$ & $\begin{array}{l}\text { Are you resigned to the problems you are } \\
\text { experiencing? } \\
\text { What feelings does resignation cause in you? } \\
\text { Do you think you could find something } \\
\text { constructive, positive in resignation? } \\
\text { Do you feel capable of changing your attitude } \\
\text { in order to not remain resigned? }\end{array}$ & $\begin{array}{l}1 . \\
2 . \\
3 . \\
4 . \\
5 . \\
6 . \\
7 . \\
8 . \\
9 .\end{array}$ & $\begin{array}{l}\text { Do you think that acceptance is the same as } \\
\text { resignation? } \\
\text { What elements do you consider to be different in } \\
\text { these two concepts? } \\
\text { Do you resign yourself to the problems you are } \\
\text { experiencing? } \\
\text { For what reasons do we tend to resign ourselves? } \\
\text { Is it typical of resignation to bring about emotional } \\
\text { discomfort? } \\
\text { Are you aware that you have resigned since you } \\
\text { have not let go of personal preferences? } \\
\text { Do you think that resignation blocks possible } \\
\text { options for overcoming problems? } \\
\text { Do you think you could find something } \\
\text { constructive, positive in resignation? } \\
\text { Do you feel capable of changing your attitude in } \\
\text { order to not remain resigned? }\end{array}$ \\
\hline $\begin{array}{c}\text { Spiritual } \\
\text { Dimension }\end{array}$ & $\begin{array}{l}52 . \\
53 . \\
54 . \\
55 . \\
56 .\end{array}$ & $\begin{array}{l}\text { Does suffering bring you closer to the } \\
\text { transcendental, to divinity? } \\
\text { Is faith or spirituality important to you? Can } \\
\text { you tell me in what way? } \\
\text { Do you think that hope and personal belief in a } \\
\text { deity, doctrine or teaching of a religion help } \\
\text { you cope with this situation? } \\
\text { Would suffering lead to a new life? } \\
\text { Does faith bring you peace? } \\
\text { Has faith brought about a transformation in } \\
\text { your way of thinking, living, and feeling? } \\
\text { Does faith show you in the events of your life } \\
\text { the expression of the will of a God or Gods? } \\
\text { What would be the primary interest in your } \\
\text { life that gives meaning to your life: Your } \\
\text { values, the satisfaction of your instincts and } \\
\text { impulses or the struggles of adaptation and } \\
\text { adjustment to your environment and society? }\end{array}$ & $\begin{array}{l}1 . \\
2 . \\
3 . \\
4 . \\
5 .\end{array}$ & $\begin{array}{l}\text { What do you understand by spirituality? } \\
\text { Is spirituality important to you? } \\
\text { Does spirituality bring you peace? } \\
\text { Do you feel that a kind of providence or higher } \\
\text { will is at work in your life? } \\
\text { Has spirituality brought about a transformation in } \\
\text { the way you think, live, and feel? } \\
\text { Do you believe that belief in a deity, doctrine or } \\
\text { religion can help you cope with the situation you } \\
\text { are going through? Does it help you? } \\
\text { Could you tell me about the relationship between } \\
\text { pain, suffering, and spirituality? } \\
\text { What would be the primary interest in your life } \\
\text { that gives meaning to your life: Your values, the } \\
\text { satisfaction of your instincts and impulses or the } \\
\text { struggles of adaptation and adjustment to your } \\
\text { environment and society? }\end{array}$ \\
\hline $\begin{array}{c}\text { Verbal and } \\
\text { non-verbal } \\
\text { communica- } \\
\text { tion }\end{array}$ & $\begin{array}{c}61 . \\
62 . \\
63 . \\
64 . \\
65 . \\
66 .\end{array}$ & $\begin{array}{l}\text { Do you think non-verbal communication is } \\
\text { important? } \\
\text { Does non-verbal communication improve } \\
\text { empathy? } \\
\text { Do you guess when the other person wants to } \\
\text { finish talking without needing to be told? } \\
\text { Do you pay more attention to body language } \\
\text { or verbal language? } \\
\text { Do you achieve your objectives in your } \\
\text { conversations with others? } \\
\text { Do you get everyone to listen to you when you } \\
\text { speak without difficulty? } \\
\text { Are you intuitive and can you read other } \\
\text { people's minds before they speak to you? } \\
\text { Do you easily empathize with the people you } \\
\text { talk to? Do you put yourself in their shoes? } \\
\text { What are the advantages of good } \\
\text { communication? } \\
\text { What are the characteristics of efficient } \\
\text { communication for you? }\end{array}$ & $\begin{array}{l}1 . \\
2 . \\
3 . \\
4 . \\
5 . \\
6 . \\
7 . \\
8 . \\
9 . \\
10 . \\
11 .\end{array}$ & $\begin{array}{l}\text { Are you communicative with others? } \\
\text { Do you like or need to communicate? } \\
\text { What is your purpose in communicating? } \\
\text { Do you pay more attention to body language or } \\
\text { verbal language? } \\
\text { Do you think that non-verbal communication is } \\
\text { important? } \\
\text { Does non-verbal communication enhance } \\
\text { empathy? } \\
\text { Do you empathize easily with the people you talk } \\
\text { to, do you put yourself in their shoes? } \\
\text { Do you achieve your goals in your conversations } \\
\text { with others? } \\
\text { Do you usually manage to be listened to when you } \\
\text { speak without much difficulty? } \\
\text { Are you intuitive and can you anticipate what } \\
\text { others are thinking before they speak to you? } \\
\text { What are the characteristics of effective } \\
\text { communication for you? }\end{array}$ \\
\hline
\end{tabular}


Table A1. Cont.

\begin{tabular}{|c|c|c|}
\hline Categories & Initial Items & Final Items \\
\hline Pain & $\begin{array}{l}\text { 67. How are you? } \\
68 . \text { How do you feel? } \\
69 . \text { Do you manage on your own or do you need } \\
\text { support in everyday life? } \\
\text { 70. Do you have a lot of pain and how severe is it? } \\
\text { 71. When did the illness start? } \\
\text { 72. Have you been in hospital for a long time? } \\
\text { 73. What jobs did you have before your illness? } \\
\text { 74. Where will you go when you leave the } \\
\text { h5. What do you think is causing your pain? }\end{array}$ & $\begin{array}{l}\text { 1. Do you feel physical pain? } \\
\text { 2. How would you rate it/them in terms of level of } \\
\text { intensity? } \\
\text { 3. What do you think is causing your pain? } \\
\text { Have you ever been hospitalized for your pain or } \\
\text { 5. Do you manage on your own or do you need } \\
\text { s. } \quad \begin{array}{l}\text { If you could remove something from your life at } \\
\text { the touch of a button, what would you remove? }\end{array} \\
\text { 7. Does physical pain make you suffer mentally? } \\
\text { 8. How do you feel right now? Tell me about your } \\
\text { feelings and your current state? } \\
\text { 9. Tell us about your condition, about your vital } \\
\text { decline, in order for us to be clear about your } \\
\text { condition and the way of life you are facing. Tell } \\
\text { us as much as you feel appropriate to describe, } \\
\text { complain, to develop your experience... your life } \\
\text { story about your pain. }\end{array}$ \\
\hline Fear & $\begin{array}{l}\text { 76. Are you afraid of this situation you are going } \\
\text { through? } \\
\text { 77. What physiological symptoms do you have } \\
\text { when you are afraid? } \\
\text { 78. How do you behave when you are afraid of } \\
\text { losing what you have in your life? } \\
\text { 79. How would you categorize your fear-distant, } \\
\text { near or somewhere in between? } \\
\text { 80. How do you manage your fear? }\end{array}$ & $\begin{array}{l}\text { 1. Are you afraid of your current situation? } \\
\text { 2. What are you afraid of? } \\
\text { 3. How do you behave when you are afraid? } \\
\text { 4. How does fear express itself in your body? } \\
\text { 5. How do you react to the loss of what you have? } \\
\text { 6. How would you define your fear, of the present, of } \\
\text { the future? } \\
\text { 7. Do you consider fear to be a major obstacle to } \\
\quad \text { spiritual development and creativity? }\end{array}$ \\
\hline Transience & $\begin{array}{l}\text { 81. What feelings, emotions and thoughts does the } \\
\text { memory of your past cause you? } \\
\text { 82. Are you aware of the transience of life? } \\
\text { 83. What strengths did you learn from the events } \\
\text { that caused you suffering in your past? } \\
\text { 84. What strengths do you have in your present } \\
\text { life, could you describe them? } \\
\text { 85. What is most important at this moment in your } \\
\text { life? }\end{array}$ & $\begin{array}{l}\text { 1. When you think about your past, about the } \\
\text { memories of your life, what feelings, emotions or } \\
\text { thoughts come to you? } \\
\text { 2. Are you aware of the transience of life and why? } \\
\text { 3. What did you learn from past situations of } \\
\text { suffering? } \\
\text { 4. What strengths did you discover or learn that you } \\
\text { had from the events that caused you suffering in } \\
\text { your past? } \\
\text { What strengths do you have in your present life, } \\
\text { 6. What you describe them? } \\
\text { this moment? }\end{array}$ \\
\hline Gratitude & $\begin{array}{l}\text { 86. How do you feel when you are generous or } \\
\text { grateful to others? } \\
\text { 87. Have you ever not been generous or grateful? } \\
\text { 88. Have others been generous or grateful to you? } \\
\text { 89. Did you appreciate or not appreciate the } \\
\text { suffering event? } \\
\text { 90. Why were you grateful or ungrateful? }\end{array}$ & $\begin{array}{l}\text { 1. Do you consider yourself a grateful person? } \\
\text { 2. } \quad \begin{array}{l}\text { Do you usually thank other people, God or life } \\
\text { (depending on your beliefs) for the good things in }\end{array} \\
\text { your life? } \\
\text { 3. Are others usually grateful to you? } \\
\text { 5. Are you feel gratitude for being alive? } \\
\text { 6. Are you grateful for your life trajectory/luck? } \\
\text { 7. Do you feel grateful for having enjoyed some } \\
\text { 8. Tell me about a time when you were not generous } \\
\text { things in life? Which ones? } \\
\text { 9. Tell me about a time when someone was grateful } \\
\text { to you. }\end{array}$ \\
\hline
\end{tabular}


Table A1. Cont.

\begin{tabular}{|c|c|c|}
\hline Categories & Initial Items & Final Items \\
\hline Compassion & $\begin{array}{l}\text { 91. How do you act towards yourself during } \\
\text { difficult times? } \\
\text { 92. How do you show compassion to people who } \\
\text { have hurt you or others? } \\
\text { 93. Would you define your compassion as positive } \\
\text { or negative and why? } \\
\text { 94. Do you show compassion for others and help } \\
\text { them to alleviate their suffering? }\end{array}$ & 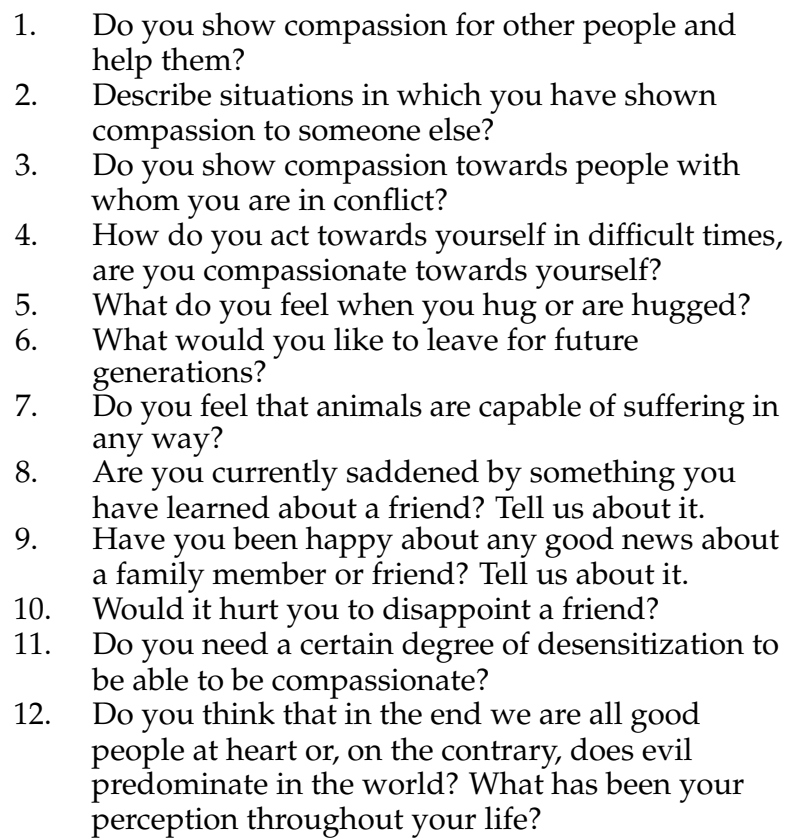 \\
\hline
\end{tabular}

95. What plans would you like to make with your family?

1. What is hope for you?

96. What kind of life would you like to create from

2. Can you differentiate hope from delusion or a now on?

2. Can you differ

97. Can you learn to have hope and to be hopeful What hope and illusion has there been in your life?

Hope $\quad 97$. for others?

4. How have delusion and hope served you?

98. Where can you learn to live in hope?

99. Is hope the expectation or waiting with patience to receive that which we do not yet see?

5. Can you learn to have hope (illusion, dreams)?

6. Can you be hopeful for others?

100. What do you think are the benefits of being a carer?

Palliative care 101. Have you ever cared for someone?

102. Did it teach you or did you learn anything from the situation or the person you cared for?
1. Have you ever taken care of someone?

2. Tell me about a situation in which you have cared for someone.

3. What benefits did you get from being a carer? What did you learn?

4. How did you feel?

5. What emotions do you experience when caring for someone who is suffering?

6. Do you feel that you identify too much when contemplating the suffering of another person?

7. What training is required to be a carer?
103. Are you sad about the situation you are in?

104. Could you control your sadness and how would you do it?

Sadness sad: Feeling down, little interest in doing things, sleeping too much, low energy, little or too much appetite, agitated or sluggish, poor concentration, negative thoughts?

1. In what situations are you sad?

2. Do you often allow yourself to be sad?

3. How do you cope with sadness and what would you do to feel better?

4. Do you think you would need help and resources to cope with times when you feel sad?

5. Relate sadness to the bodily tensions that you perceive in your body?

6. What symptoms do you have when you feel sad?

7. How do you relate to others when you are sad?

8. Do you think that spiritual understanding would alleviate sadness?

9. Could you control your sadness and how would you do it? 
Table A1. Cont.

\begin{tabular}{|c|c|c|}
\hline Categories & Initial Items & Final Items \\
\hline Resilience & $\begin{array}{l}\text { 106. What do you do when you are in pain? } \\
\text { 107. Do you take on and face problems with } \\
\text { courage? } \\
\text { 108. Are you consistent enough to work for a long } \\
\text { time in order to achieve your goals? } \\
\text { 109. Have you had help, support from other people } \\
\text { to get out of the situation that was causing you } \\
\text { suffering? }\end{array}$ & $\begin{array}{l}\text { 1. Are you positive in the face of problems? } \\
\text { 2. Do you have confidence in your ability to } \\
\text { 3. Do you face problems with determination? } \\
\text { 4. How do you respond to suffering? } \\
\text { 5. How do you think it helps to escape from the } \\
\text { things that make us suffer? } \\
\text { 6. How do you think it helps to face the things that } \\
\text { make us suffer? } \\
\text { 7. What is the best way to deal with the things that } \\
\text { 8. What can we do when we suffer a lot? } \\
\text { 9. Is it enough to seek comfort when we suffer or are } \\
\text { there other approaches? } \\
\text { 10. Are you consistent enough to work for a long time } \\
\text { 11. Have you had help from other people to get out of } \\
\text { the situation that was causing you suffering? } \\
\text { 12. Do you help other people who have problems? } \\
\text { 13. Does it help at all to have suffered in life? }\end{array}$ \\
\hline Happiness & $\begin{array}{l}\text { 110. Are you happy with your new situation? } \\
\text { 111. Are the reasons why you feel happy or } \\
\text { unhappy inside you or are they external? } \\
\text { 112. Would happiness be a change in your thinking } \\
\text { and attitude? } \\
\text { 113. How could you attenuate your suffering in } \\
\text { order to be happier? } \\
\text { 114. Does the acceptance of suffering produce } \\
\text { happiness? }\end{array}$ & $\begin{array}{l}\text { 1. What does happiness mean to you? } \\
\text { 2. Tell me about times when you felt that your life } \\
\text { was joyful, engaged, and meaningful. In relation } \\
\text { to this question, tell me about how you feel } \\
\text { nowadays. } \\
\text { 3. } \begin{array}{l}\text { Do you consider the reasons for happiness to be } \\
\text { internal or external? }\end{array} \\
\text { 4. Will your happiness always be the happiness of } \\
\text { others? } \\
\text { 5. } \begin{array}{l}\text { Do you believe that a change in thinking, values, } \\
\text { and attitude can change a situation and bring relief }\end{array} \\
\text { rather than suffering? } \\
\text { 6. Is it enough to change the way you think to be } \\
\text { happy? Or is it enough to change the external } \\
\text { conditions? What can individuals do on both } \\
\text { levels? } \\
\text { How do you feel when you are happy or when } \\
\text { you have been happy? } \\
\text { 8. Have you ever felt undeserving of happiness? } \\
\text { Why? } \\
\text { Is it possible to be fully happy? } \\
\text { Are people to blame for their misfortune? For their } \\
\text { situation? For their misery? For their physical } \\
\text { state? For their leaders? For wars? For COVID-19? } \\
\text { 11. How could you lessen your suffering in order to } \\
\text { be happier? }\end{array}$ \\
\hline
\end{tabular}

Source: Author's own elaboration.

\section{References}

1. Krikorian, A.; Limonero, J.T.; Maté, J. Suffering and distress at the end-of-life. Psycho Oncol. 2012, 21, 799-808. [CrossRef] [PubMed]

2. Cassell, E.J. The Nature of Suffering and the Goals of Medicine. N. Engl. J. Med. 1982, 306, 639-645. [CrossRef]

3. Broggi, M.A. Por Una Muerte Apropiada; Editorial Anagrama: Barcelona, Spain, 2013.

4. Epicteto. Disertaciones Por Arriano; Gredos: Madrid, Spain, 1993.

5. Schopenhauer, A. El Mundo Como Voluntad y Representación I. Exit Imagen Cult. 2019, 38, 114.

6. Lewis, S.E. Trauma and the Making of Flexible Minds in the Tibetan Exile Community. Ethos 2013, 41, 313-336. [CrossRef]

7. Middleton, H. Flourishing and Posttraumatic Growth. An Empirical Take on Ancient Wisdoms. Health Care Anal. 2016, 24, 133-147. [CrossRef] [PubMed]

8. Bueno-Gómez, N. Conceptualizing suffering and pain. Philos. Ethics Humanist. Med. 2017, 12, 7. [CrossRef] [PubMed]

9. Gómez, M. Dolor y Sufrimiento Al Final de La Vida; Arán Ediciones: Madrid, Spain, 2007. 
10. Biedma, L.; García, M.I.; Serrano, R. Centro de Investigaciones Sociológicas. Opiniones y Actitudes No. 77. Percepciones Sociales Del Dolor. 2019. Available online: http:/ / www.cis.es/publicaciones/OyA/ (accessed on 10 January 2021).

11. Pocino, M.; Luna, G.; Canelones, P.; Mendoza, A.; Romero, G.; Palacios, L.; Rivas, L.; Castés, M. La relevancia de la intervención psicosocial en pacientes con cáncer de mama. Psicooncología 2007, 4, 59-73.

12. VanderWeele, T.J. Suffering and response: Directions in empirical research. Soc. Sci. Med. 2019, 224, 58-66. [CrossRef]

13. Gibson, J. A Relational Approach to Suffering: A Reappraisal of Suffering in the Helping Relationship. J. Humanist. Psychol. 2017, 57, 281-300. [CrossRef]

14. Wierzbicka, A. "Pain" and "suffering" in cross-linguistic perspective. Int. J. Lang. Cult. 2014, 1, 149-173. Available online: http:/ / www.jbe-platform.com/content/journals/10.1075/ijolc.1.2.02wie (accessed on 10 January 2021). [CrossRef]

15. Mintz, A.I. The happy and suffering student? Rousseau's Emile and the path not taken in progressive educational thought. Educ. Theory 2012, 62, 249-265. [CrossRef]

16. Pigem, J. La Fuerza de la Compasión. 2020. Available online: http://urano.blob.core.windows.net/share/i_Prensa/1039/La\%20 fuerza \%20de\%20la\%20compasion.pdf (accessed on 16 July 2021).

17. Robustelli, B.; Whisman, M. Gratitude and Life Satisfaction in the United States and Japan. J. Happiness Stud. 2018, 19, 41-55. Available online: http:/ /link.springer.com/10.1007/s10902-016-9802-5 (accessed on 24 October 2021). [CrossRef]

18. Brady, M.S. Suffering and Virtue; Oxford University Press: New York, NY, USA, 2018.

19. Carrillo Canán, A. Dolor y Sufrimiento en Nietzsche o la Crianza del Héroe. Elementos: Ciencia y Cultura. 2002. Available online: https:/ / www.researchgate.net/publication/26419371_Dolor_y_sufrimiento_en_Nietzscheolacrianza_del_heroe (accessed on 16 July 2021).

20. Orellana, I. Pedagogía del Dolor; Palabra: Madrid, Spain, 1999.

21. Jaspers, K. Psicopatología General; Fondo de Cultura Económica: Mexico City, Mexico, 1993.

22. Anguera, M.T. Innovaciones en la metodología de evaluación de programas. Ann. Psychol. 1989, 5, 13-42.

23. Brown, F. Principios de la Medición en Psicología y Educación; El Manual Moderno: Mexico City, Mexico, 1980.

24. Díaz, L.P.; Muñoz, A.I.; Vargas, D. Confiabilidad y validez del cuestionario de espiritualidad de Parsian y Dunning en versión española. Rev. Lat.-Am. Enferm. 2012, 20, 559-566.

25. Alarcón, A.M.; Muñoz, S. Medición en salud: Algunas consideraciones metodológicas. Rev. Méd. Chile 2008, 136, 125-130.

26. Carvajal, A.; Centeno, C.; Watson, R.; Martínez, M.; Sanz, A. ¿Cómo validar un instrumento de medida de la salud? An. Sist. Sanit. Navar. 2011, 34, 67-72. [CrossRef]

27. Chacón, S.; Pérez, J.A.; Holgado, F.P.; Lara, Á. Evaluación de la calidad universitaria: Validez de contenido. Psicothema 2001, 13, 294-301.

28. Carretero, H.; Pérez, C. Normas para el desarrollo y revisión de estudios instrumentales. Int. J. Clin. Health Psychol. 2005, 5, 521-551.

29. Soriano, A.M. Diseño y validación de instrumentos de medición. Diálogos 2014, 14, 19-40.

30. Hernández-Hernández, E.; Andrés, J.M.P. Design and validation of a set of observational instruments to assess a team's match execution in volleyball. J. Sport Health Res. 2013, 5, 43-56.

31. Viedma, A.; Entrevistas, E.J. Callejo Gallego (Coord). In Introducción a las Técnicas de Investigación Social; Ramos Areces: Madrid, Spain, 2010; pp. 63-94.

32. Bolívar, A.; Domingo, J.; Fernández, M. La Investigación Biográfico-Narrativa en Educación; La Muralla: Madrid, Spain, 2001.

33. Ohlén, J. Practical Wisdom: Competencies Required in Alleviating Suffering in Palliative Care. J. Palliat. Care 2002, 18, 293-299. [CrossRef] [PubMed]

34. Kvale, S. Las Entrevistas en Investigación Cualitativa; Morata: Madrid, Spain, 2011.

35. Frankl, V.E. El Hombre en Busca de Sentido; Herder: Barcelona, Spain, 2015.

36. Páez-Blarrina, M.; Gutiérrez-Martínez, O.; Valdivia, S.; Luciano, C. Terapia de Aceptación y Compromiso (ACT) y la importancia de los valores personales en el contexto de la terapia psicológica. Int. J. Psychol. Psycholog. Ther. 2006, 6, 1-20.

37. Rizo, D. ¿Aceptación o Resignación? 2013. Available online: https:/ /www.doloresrizopsicologa.es/aceptacion-o-resignacion/ (accessed on 5 October 2021).

38. Rojas, M. Cómo Hacer Que Te Pasen Cosas Buenas; Espasa: Barcelona, Spain, 2018.

39. De Melo, M.E.; Ferreira, A.C. Cuidados paliativos: Narrativas del sufrimiento en la escucha del otro. Rev. Bioét. 2015, 23, 346-354. [CrossRef]

40. Lewis, C.S. El Problema del Dolor; Rialp: Madrid, Spain, 2018.

41. Adorna, R. El origen de la Infelicidad; Desclée de Brouwer: Bilbao, Spain, 2015.

42. Strauss, C.; Lever-Taylor, B.; Gu, J.; Kuyken, W.; Baer, R.; Jones, F.; Cavanagh, K. What is compassion and how can we measure it? A Review of definitions and measures. Clin. Psychol. Rev. 2016, 47, 15-27. [CrossRef]

43. Goleman, D. La Práctica de la Inteligencia Emocional; Kairós: Barcelona, Spain, 1999.

44. Chaves, C.; Hervás, G.; García, F.E.; Vázquez, C. Building Life Satisfaction Through Well-Being Dimensions: A Longitudinal Study in Children with a Life-Threatening Illness. J. Happiness Stud. 2015, 17, 1051-1067. [CrossRef]

45. Álava, M.J. La Inutilidad del Sufrimiento; La Esfera de los Libros: Madrid, Spain, 2003.

46. Aiken, L.R. Content validity and reliability of single items or questionnaires. Educational and. Psycholog. Meas. 1980, 40, 955-959. Available online: https:/ / www.researchgate.net/ (accessed on 19 October 2021). [CrossRef] 
47. Aiken, L.R. Three coefficients for analyzing the reliability and validity of ratings. Educ. Psycholog. Meas. 1985, 45, 131-142. [CrossRef]

48. Hambleton, R.K. Validating the Test Score. In A Guide to Criterion-Referenced Test Construction; Berk, R.A., Ed.; Johns Hopkins University Press: Baltimore, Spain, 1984; pp. 199-230.

49. Pedrosa, I.; Suárez-Álvarez, J.; García-Cueto, E. Evidencias sobre la Validez de Contenido: Avances Teóricos y Métodos para su Estimación [Content Validity Evidences: Theoretical Advances and Estimation Methods]. Acción Psicológ. 2013, 10, 3-18. [CrossRef]

50. Penfield, R.D.; Giacobbi, P.R., Jr. Applying a score confidence interval to Aiken's item content-relevance index. Meas. Phys. Educ. Exerc. Sci. 2004, 8, 213-225. [CrossRef]

51. Merino, C.; Livia, J. Intervalos de confianza asimétricos para el índice la validez de contenido: Un programa Visual Basic para la $\mathrm{V}$ de Aiken [Confidence intervals for the content validity: A Visual Basic computer program for the Aiken's V]. An. Psicol. 2009, 25, 169-171.

52. Charter, R.A. A breakdown of reliability coefficients by test type and reliability method, and the clinical implications of low reliability. J. Gen. Psychol. 2003, 130, 290-304. [CrossRef] [PubMed]

53. Ventura-León, J. De Regreso a la Validez Basada en el Contenido; Adicciones: Barcelona, Spain, 2019. [CrossRef]

54. Napitupulu, D.; Syafrullah, M.; Rahim, R.; Amar, A.; Sucahyo, Y.G. Content validity of critical success factors for e-Government implementation in Indonesia. In IOP Conference Series: Materials Science and Engineering; IOP Publishing: Bristol, UK, 2018; Volume 352, p. 012058. [CrossRef]

55. Fleiss, J.L. The Design and Analysis of Clinical Experiments; John Wiley \& Sons: New York, NY, USA, 1986.

56. Landis, J.R.; Koch, G.G. The measurement of observer agreement for categorical data. Biometrics 1977, 33, 159-174. [CrossRef]

57. Weird, J.P.; National Strength and Conditioning Association. Quantifying test-retest reliability using the intraclass correlation coefficient and the SEM. J. Strength Cond. Res. 2005, 19, 231-240. [CrossRef]

58. Rodríguez Gómez, G.; Gil Flores, J.; García Jiménez, E. Metodología de la Investigación Cualitativa; Aljibe: Málaga, Spain, 1999. 